\title{
Photochemical Wastewater Treatment for Potential Agricultural Use
}

\section{SANDRA GARCÍA ${ }^{1}$, FERNANDO HERNÁNDEZ ${ }^{2 *}$, AGUSTIN ARAGÓN ${ }^{1}$, JOSÉ ANTONIO RIVERA ${ }^{3}$ and ROLANDO RUEDA ${ }^{4}$}

\author{
${ }^{1}$ Posgrado en Manejo Sostenible de Agroecosistemas. \\ ${ }^{2}$ Centro de Química del Instituto de Ciencias. \\ ${ }^{3}$ Centro de Investigaciones en Ciencias Microbiológicas del Instituto de Ciencias. \\ ${ }^{4}$ Departamento de Investigación en Ciencias Agrícolas, \\ Benemérita Universidad Autónoma de Puebla, México.
}

http://dx.doi.org/10.12944/CWE.9.3.15

(Received: October 28, 2014; Accepted: December 17, 2014)

\begin{abstract}
The urban wastewaters after advanced primary treatment (APT) are again discharged into the river without any use. In the present research in a soilless culture system where maize seedlings were tested three different treatments were planted: 1. Obtained from the effluent water of an APT, 2. Photochemically treated wastewater (PCT) and 3. Urban water network (UW). A block randomly distributed design was tested, with five repetitions where the experimental unit was formed by a 36 cavities filled with Peat Moss and the useful plot was considered by 16 central plants for each experimental unit. Irrigations were scheduled since the first time of the planting, employed $27 \mathrm{~mL} /$ cavity. The removal of the organic contaminants present into the water was conducted by the employment of a Batch photoreactor, adapted with a recirculation system $\left(\mathrm{UV} / \mathrm{H}_{2} \mathrm{O}_{2} / \mathrm{O}_{3}\right)$, evaluated to determine UV-Vis spectra, $\mathrm{pH}$, color and turbidity parameters initial and final samples. Measurements of height and percentage of germination in plants, where is determined that the seedlings irrigated with water PCT were reached the highest average compared to APT and UW irrigated; After the $50 \mathrm{~cm}$ growing plant, a determination of the presence of heavy metal, via atomic absorption method, were carried on analyzing the leaves, roots and stalks of the samples. Concluding that the presences of heavy metals into the APT were higher than PCT treatments, it can be an impediment for the normal growing of the plants. Therefore, the application of the photochemical treatment using $\left(\mathrm{UV} / \mathrm{H}_{2} \mathrm{O}_{2} / \mathrm{O}_{3}\right)$ system, represent a viable alternative for the wastewater treatment after the APT process to possible use of irrigation.
\end{abstract}

Key words: Wastewater, Photochemical treatment, Advanced primary treatment,Corn cultivation, Water-reuse.

\section{INTRODUCTION}

Water is one of the most important chemical compounds for the human and life in general. In a pure quantitative aspect, water covers approximately the $71 \%$ of the terrestrial surface and the live matter includes soaring composition percentages of that substance, form to a qualitative standpoint, all the life forms needs an important amount of water to perform their biological functions, such as of the nutrition and excretion of the live beings are based thereon ${ }^{1}$. Actually the amount of clean water available to use is limited around world, for these reason is important to use residual wastewater, as clean as possible. There is evidence of the reuse of residual wastewater into the agriculture of the Greek and Roman civilizations ${ }^{2}$. Agriculture uses around the $70 \%$ of water available, are expected in times and 
regions where the water is scarce, farmers adopt the use urban or domestic wastewater as alternative of source of water to irrigation. Although water recycled is a relatively small part of the total water supply, it could solve some of the agriculture problems.

Many crops varieties use regenerated water under adequate conditions such as farming crops (corn, barley, oats, wheat), fiber and seed crops ( cotton, seeds of flowers), vegetable crops (broccoli, cabbage, celery, cauliflower) or forage (alfalfa, hay, grass) $)^{3-6}$.

It has been estimated that the Earth contains $1,351,000 \mathrm{Km}^{3}$ of water. Only the $3 \%$ is fresh water, i.e. suitable for drink, hygiene, agriculture and industry. Most of the freshwater is far away of the civilization or in regions with difficult access to be grasped for is use. The Food and Agriculture Organization (FAO) estimates that only 9,000 to $14,000 \mathrm{~km}^{3}$ are economically available for the human consumption per year ${ }^{7}$. The Mundial population is growing up at a rate of approximately $1.2 \%$ per year and it is predicted that it will be increased at 9,000 million on 2030. Provide adequate water to these people will be a great challenge; the water is not only essential for the direct human consumption and for the households, but also for the food production and other manufactured issues needed for living and its improving standards. The daily requirement of water is of 2 or $4 \mathrm{~L}$ per person, while the food productions consume 2000 to $5000 \mathrm{~L}$ per capita to satisfy the global demand. As a result, the agriculture is the major consumer of water, given that it represents almost the $70 \%$ of all the extractions, reaching until a $95 \%$ into the development countries, with an increasing demand ${ }^{8}$.

The reuse of the treated wastewater into agriculture is an option that has been studied and adopted increasingly in regions with shortage of water. A lot of regions around the world have experienced gradually problems of water deficit. This is due to the relentless growth of water demand against static or decreased water resources and the periodic droughts caused by climatic factors. Is probably that the climate change exacerbates water scarcity, global warning of 2 centigrade could lead to a situation in which "100 to 400 millions of persons could be at risk of hunger and approximately two billion of humans do not have water to satisfy their consumption needs, sanitation and foods (World Bank, 2009).

Lack of water resources has led to increased recycling of domestic and municipal sewage (whether treated or untreated) for irrigation. For the recycling of the water for that purposes, is necessary to reached a quality to prevent public health diseases and that the obtained agricultural products have acceptance into the market. The development of the agricultural sector is the most important phase and the initial stage into the economic development and the welfare of a lot of countries the agriculture remains the key of the alimentary security and sovereignty and the growing factor of the great part of the world.

According to the NOM-002-ECOL-1996" the residual wastewaters are defined as: the waters with varied composition discharges from urban, industrial, commercial, services, agribusiness, livestock, domestic, including fractionations and in general any other uses and the mixture thereof.

\section{Advanced Primary Treatment}

In search of improved water quality, in the early 70's he appeared an alternative processing wastewater, named physicochemical treatment, appeared. Actually called advanced primary treatment (APT), this alternative has been used with successfully into developed countries. The APT is a treatment system that consists into the removal of the most of the colloidal and biological pathogens constituents from wastewater, through the coagulation, flocculation, sedimentation, filtration and disinfection methods ${ }^{10}$. The wastewater treated or effluent is transparent due to the nearly complete elimination of suspended solids, pathogen organisms, and the major part of the Biochemical Oxygen Demand (BOD) and the phosphorus of the residual wastewater.

\section{Photochemical Processes}

Those processes involve chemical reactions that occur by the influence of the absorption of UVVis radiation, either the Sun or other source, where its reactions kinetic could be increased by the addition of $\mathrm{H}_{2} \mathrm{O}_{2}, \mathrm{O}_{3}$, metallic salts or semiconductor. Accordingly to Sandip Sharma and coworkers ${ }^{11}$, 
the photochemical processes provide the following advantages into the water and effluent treatment, which are not limited to the utilization of $\bullet \mathrm{OH}$ radical as oxidant.

- Avoids the use of $\mathrm{O}_{3}$ or reduce its proportion.

- Increment the velocity of the reaction, if it is compared with the same technique in absence of light.

- Exclude drastic changes of $\mathrm{pH}$.

- Permits the use of variety of oxidants.

- Decreased operating costs.

- Is not a selective oxidant.

- $\quad$ No reaction by products or are formed in low concentrations.

- $\quad$ Generally, improve the organoleptic properties of the treated water.

These free radicals $(\bullet \mathrm{OH})$, possess the adequate properties to attack virtually all organic compounds and reacts with $10^{6}$ to $10^{12}$ times faster than the other alternative oxidants like $\mathrm{O}_{3}$. The efficiency of the photochemical destruction of a determinate compound could be altered drastically in function of the reactor design (type of lamp, geometry, hydrodynamic, turbulence, etc.), which impacts on the electric energy consumption and the $\operatorname{costs}^{11}$.

\section{MATERIALS AND METHODS}

\section{Photochemical process}

The removal of the organic contaminants presents into the water coming from an APT, it was carried on through the use of batch photoreactor adapted to recirculation in a $\mathrm{UV} / \mathrm{H}_{2} \mathrm{O}_{2} / \mathrm{O}_{3}$ system. The reactor has a $1 \mathrm{~L}$ capacity and is equipped with a mercury medium-pressure steam UV lamp (model PUV-1022, Heraeus, Frankfurt, Germany), which is $110 \mathrm{~mm}$ length and uses $1000 \mathrm{~W}, 145 \mathrm{~V}$ and $7.5 \mathrm{~A}$. The lamp is protected by a quartz tube. The reactor has a distilled water circulating system to regulate the temperature. The reaction vessel is made of Pyrex glass, which in the upper part has two inlets and in the lower part an inlet for the air or air/ozone flow. To generate ozone, we used a King Ozone Hydrozon K-40 generator, which produces $40 \mathrm{mg}$ of ozone per hour. the lamp has the highest emission wavelength between 200 and $460 \mathrm{~nm}$ equal length which absorbs most of the organic functional groups and which is carried out the formation of the radical -OH finally was evaluated to obtain the spectra UVvis initial and final samples.

After the obtaining of a sample of composed water coming from a APT, that was poured into the qualitative paper filters with a retention of $1.5 \mu \mathrm{m}$, with the finality to clarify and eliminate the precipitates of

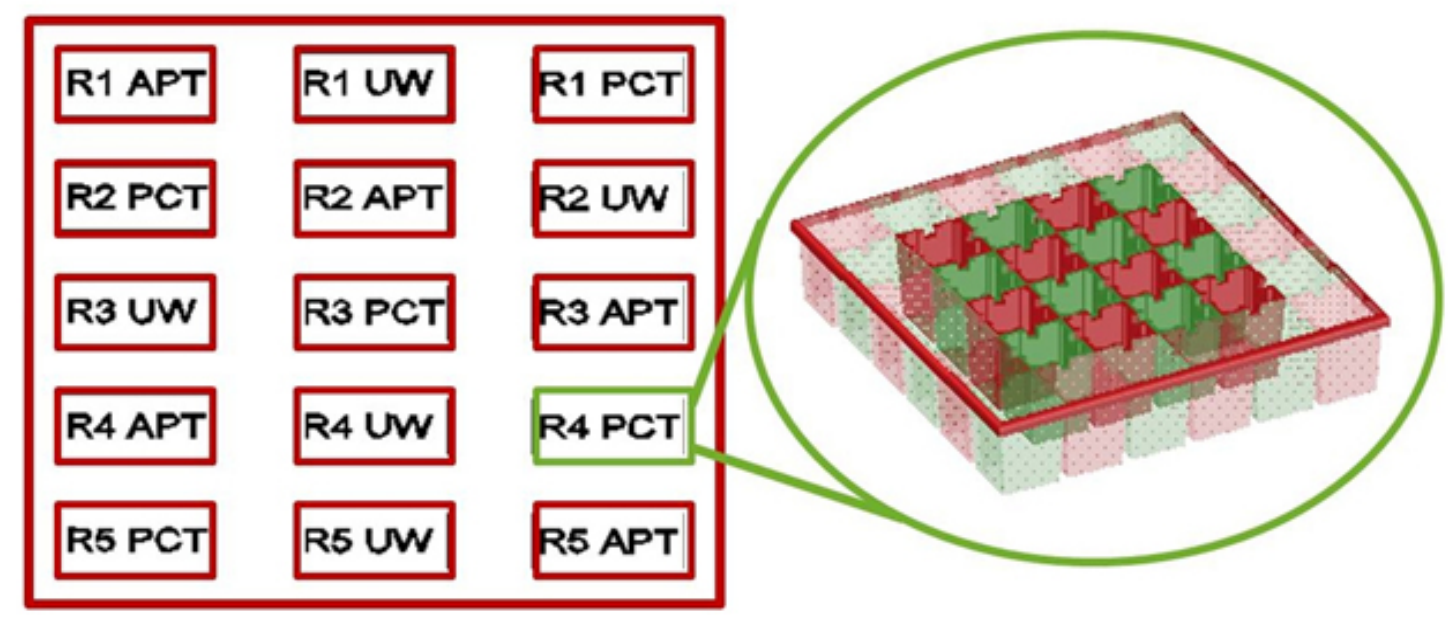

Fig. 1: (a) Completely Randomized Design (CRD) used for the planting of corn seedlings. b) Plot helpful 
the sample. Once obtained the aliquots the specific analysis were carried on, given a quantification of the following parameters:

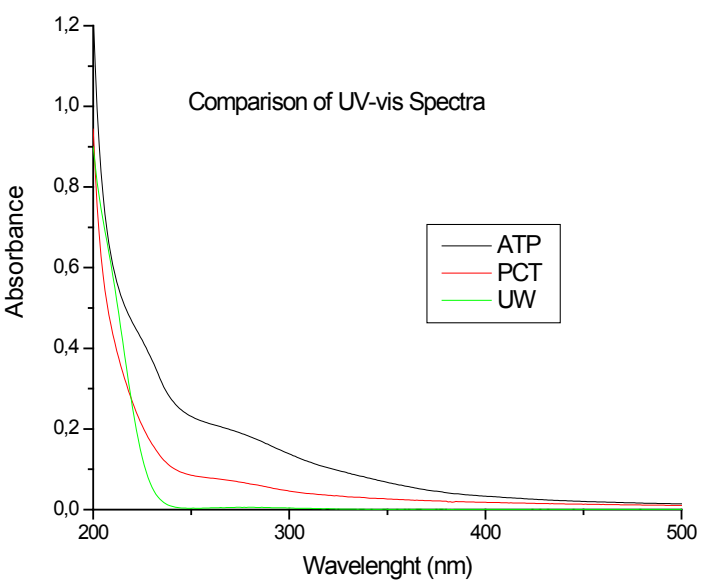

Fig. 2: UV-Vis spectra comparison used into the different treatments applied onto the corn seedlings
Determination of $\mathrm{pH}$, electrical conductivity and total suspended solids was carried out with Conductronic equipment, model PC-16. The residual hydrogen peroxide content (or other peroxides that formed when ozone was used) were determined using the paper indicator, peroxide test 25 (0.5-25 $\mathrm{mgL}^{-1}$ ) from Merck. The UV-Vis Spectrum were determined by spectrophotometer Perkin Elmer, model Lambda 20.

The wastewater characterization and monitoring of experiments were performed using a photometer SQ118 of MERCK, applying the methods of analysis Spectroquant ${ }^{\circledR}$ program with kit tests: color, turbidity, COD, Cu, Cd, Cr, Pb, Zn, Fe, $\mathrm{Mn}$ and Ni using the methods 139, 113, 105, 042, $115,106,114,103,107,045$ and 049 respectively.

Determination of the heavy metal absorption into the plants

In a soilless system, where corn seedlings which were three treatments tested was sown:

Table. 1: Comparison of the parameters into the samples of treated wastewater before and after their irradiation

\begin{tabular}{ccccc}
\hline Treatment & Turbidity (UNF*) & Color (1/m) & pH & DQOmg/L \\
\hline APT & 62 & 11.7 & 6.8 & 200 \\
PCT & 16 & 3.1 & 7.8 & 90 \\
\hline
\end{tabular}

*NFU Nefelometric unit of formazine

Table. 2: Comparison of some parameter established into the norm: NOM-CCA/032-ECOL/1993

\begin{tabular}{lccc}
\hline Parameters & $\begin{array}{c}\text { Maximun } \\
\text { permissible limits }\end{array}$ & APT & UW \\
\hline Electrical conductivity (mmho/cm) & 2000 & 686 & \\
Total suspended solids (mg/L) & 120 & 343 & $<0.025$ \\
Cadmium (mg/L) & 0.01 & $<0.025$ & $0.83^{*}$ \\
Copper (mg/L) & 0.2 & $0.68^{*}$ & 0.09 \\
Total Chromium (mg/L) & 0.1 & 0.08 & $<0.01$ \\
Iron (mg/L) & 5 & $<0.01$ & 0.03 \\
Manganese (mg/L) & 0.2 & 0.03 & 0.09 \\
Níckel (mg/L) & 0.2 & 0.20 & 0.27 \\
lead (mg/L) & 6 & 0.29 & 0.23 \\
Zinc (mg/L) & 2.00 & 0.47 & \\
\hline
\end{tabular}

* Above the maximum allowable 
a) Wastewater after advanced primary treatment an APT.

b) Water with photochemical treatment (PCT).

c) A witness who will be the Urban Network (UW).

These treatments are performed under a design of randomized complete block with five replicates (see Figure 1), where the experimental unit was composed of polystyrene trays with 36 cavities filled with Peat Moss (substrate) and the useful plot were considered the 16 central plants in each experimental unit.

It was irrigated in the early hours of the morning in accordance with each treatment, and to the needs of the plant, used the same amount of water for each treatment ( $1 \mathrm{~L}$ of water / tray, that is, approximately $27 \mathrm{~mL} /$ cavity).

The measured parameters were: germination, height, dry weight of the aerial part of the plant and of the root.

In germination the number of seeds that sprouted after 7, 10 and 15 days after establishing the experiment useful plot are quantified. Height of seedlings that formed the useful, same plot was measured with a tape measure considered from the stem base and fold up the uppermost leaf was evaluated by performing three tests at 15,30 and 45 days after planting. Once the plants reached the average of height of $50 \mathrm{~cm}, 16$ plants of the useful plot were cut, labeled, and their aerial part of the plants was separated from their roots. Was carried to constant weight in bacteriological stove at $60^{\circ} \mathrm{C}$ for a period of 3 days, after this lapse, was ground in an electric mill brand Krusty, the presence of metals in leaves, stem and root it was determined, the samples were analyzed according to atomic absorption method through Varian equipment, Model Spectra 55B.

\section{Date analysis}

The hypothesis of homogeneous variances was verified by testing Barttlet further analysis of variance according to the experimental design and multiple comparisons of means was performed using Tukey's test [12]. The Statgraphics Centurion XVI ${ }^{13}$ software was used with a confidence level of $95 \%$ for calculations and statistical tests.

\section{RESULTS AND DISCUSSION}

The results obtained from the parameters determined to form the APT affluent and after the photochemical irradiation, are showed inside the table 1

Was observed a decreased of the turbidity, color and $\mathrm{DQO}$, due to the photochemical degradation of the organic contaminants; the $\mathrm{pH}$ increase possibly for the formation of bicarbonates ${ }^{14}$. The

Table. 3: Germination, height and dry weight percentage of the corn seedling related to the irrigation treatment at different kinds of water

\begin{tabular}{|c|c|c|c|c|c|c|c|c|}
\hline \multicolumn{4}{|c|}{$\begin{array}{c}\text { Average germination } \\
\text { Treatments } \begin{array}{c}\text { percentage in days, } \\
\text { S.E. and significance. }\end{array}\end{array}$} & \multicolumn{3}{|c|}{$\begin{array}{l}\text { Averages height in } \mathrm{cm} \text {, } \\
\text { S. E. and Significance. }\end{array}$} & \multicolumn{2}{|c|}{$\begin{array}{l}\text { Averages of dry } \\
\text { weight, S. E. } \\
\text { and significance. }\end{array}$} \\
\hline & 7 days & 10 days & 15 days & 15 days & 30 days & 45 days & $\begin{array}{l}\text { Stem and } \\
\text { leaves }(g)\end{array}$ & Root (g) \\
\hline APT & $\begin{array}{r}75.00 \\
\pm 6.55 \mathrm{a}\end{array}$ & $\begin{array}{r}90.00 \\
\pm 3.75 \mathrm{a}\end{array}$ & $\begin{array}{r}96.25 \\
\pm 1.53 \mathrm{a}\end{array}$ & $\begin{aligned} & 9.10 \\
\pm & 0.10 \mathrm{a}\end{aligned}$ & $\begin{array}{r}26.40 \\
\pm 0.40 \mathrm{a}\end{array}$ & $\begin{array}{c}46.60 \\
\pm 0.40 \mathrm{a}\end{array}$ & $\begin{aligned} & 11.48 \\
\pm & 0.50 \mathrm{a}\end{aligned}$ & $\begin{array}{c}3.4 \\
\pm 0.60 \mathrm{a}\end{array}$ \\
\hline UW & $\begin{array}{r}77.50 \\
\pm 5.44 \mathrm{a}\end{array}$ & $\begin{array}{r}92.50 \\
\pm 2.33 \mathrm{a}\end{array}$ & $\begin{array}{r}96.25 \\
\pm 1.53 \mathrm{a}\end{array}$ & $\begin{array}{r}8.80 \\
\pm 0.20 \mathrm{a}\end{array}$ & $\begin{array}{c}26.60 \pm \\
0.70 \mathrm{a}\end{array}$ & $\begin{array}{r}48.10 \\
\pm 0.60 \mathrm{a}\end{array}$ & $\begin{array}{r}10.08 \\
\pm 1.03 \mathrm{a}\end{array}$ & $\begin{array}{c}3.6 \\
\pm 0.50 \mathrm{a}\end{array}$ \\
\hline PCT & $\begin{array}{r}86.25 \\
\pm 3.06 \mathrm{a}\end{array}$ & $\begin{array}{r}96.25 \\
\pm 1.53 \mathrm{a}\end{array}$ & $\begin{array}{r}97.50 \\
\pm 1.53 \mathrm{a}\end{array}$ & $\begin{array}{r}9.30 \\
\pm 0.10 \mathrm{a}\end{array}$ & $\begin{array}{r}28.30 \\
\pm 0.33 \mathrm{a}\end{array}$ & $\begin{array}{r}50.40 \\
\pm 0.40 \mathrm{~b}\end{array}$ & $\begin{aligned} & 11.84 \\
\pm & 0.87 \mathrm{a}\end{aligned}$ & $\begin{array}{c}3.0 \\
\pm 0.44 \mathrm{a}\end{array}$ \\
\hline
\end{tabular}

S.E.: standard error

Results in the same row with the same superscript were not significantly different $(p<0.05)$. 
water turbidity is due to the presence of suspended and dissolved particles. The DQO reduces due the removal of the oxidizable contaminants.

\section{UV-Vis Spectroscopy}

The figure 2 shows the comparison of the spectra determined for the different types of water samples used to irrigate the various experimental units. The spectrum of the water obtained of the effluent APT, contains a major quantity of compounds that absorbs I that region (most area under the curve), the second spectrum was obtained after the photochemical irradiation by 2 hours, of the water discharged from an APT, the initial concentration of the contaminants has been decreased (the area under the curve is minor), and the third spectrum was determined for the water used from the urban network.

Table 2 exhibited the comparison of the results obtained from the some parameters established into the Mexican official norm NOMCCA/032-ECOL/1993, that established the maximum permissible limits of contaminants into the wastewater from urban origin, for disposal by agricultural irrigation; shows that these parameters meet the current standard except copper, which is above the norms.

\section{Corn plant bioassays}

The data obtained from the rate of germination of the corn seed were submitted at the test of Bartlett for to confirmation of its homogeneity, subsequently they were subjected to the variance

Table. 4: Metals determined by atomic absorption in maize seedlings

\begin{tabular}{|c|c|c|c|c|c|}
\hline \multicolumn{6}{|c|}{ Metals at the aerial part of the plant (ppm) } \\
\hline Treatments & $\mathrm{Cu}$ & $\mathrm{Cr}$ & $\mathrm{Pb}$ & $\mathrm{Zn}$ & Cd \\
\hline UW & 0.70 & 0.06 & 0.25 & 0.19 & ND \\
\hline PCT & 0.80 & 0.04 & 0.04 & 0.14 & ND \\
\hline APT & 0.60 & 0.06 & 0.25 & 0.38 & ND \\
\hline \multicolumn{6}{|c|}{ Metals at the root of the plant (ppm) } \\
\hline UW & 1.72 & 2.0 & 0.42 & 1.3 & ND \\
\hline PCT & 0.85 & 0.16 & 0.14 & 1.6 & ND \\
\hline APT & 0.80 & 0.18 & 0.50 & 1.7 & ND \\
\hline
\end{tabular}

$\mathrm{ND}=$ No detected analysis were a significant difference cannot be observed (á d" 0.05), between the effect of the treatments. In table 3 the results of the comparison of average by Tukey's method where it can be stated that the maximum percentage of germination obtained was $97.5 \%$, where no significant difference of the effect of the treatments applied on plants, was noted. The same conclusion was perceived for the data acquired into the dry weight of the seedlings.

Accordingly to the variance analysis realized into the three evaluations of height effectuated at different growing periods of the corn seedlings, after 45 days of the sowing, a significant difference between the treatments has been founded. Likewise, the average comparison tukey's test (HSD), present two groups of averages were the effect of the photochemical treatment is statistically different $(p<0.05)$, with a height of $50.4 \mathrm{~cm}$ of the plants. Table 3.

The data obtained from the heavy metal determination by atomic absorption in both the aerial and root part of the plants, is represent in table 4 . It could be observed that the $\mathrm{Cd}$ is not detected through the method. Pál et. al ${ }^{15}$ investigated the effects caused by $\mathrm{Cd}$ in maize and reported that this element induces physiological changes such as growth inhibition, changes in the metabolism of water and ions, moreover the values of $\mathrm{Cu}$ and $\mathrm{Cr}$ are higher in the roots and lower in the aerial part of the plant after the photochemical treatment. Tolerance of the heavy metals is highly dependent of various biological, chemical and physiological adaptations into the sites contaminated with heavy metals ${ }^{16}$

\section{CONCLUSIONS}

It was determined that the $\mathrm{Cu}, \mathrm{Pb}$ and $\mathrm{Zn}$ were the elements with major concentrations for the different types of water used and it was observed the same behavior on the accumulation in both the roots and the aerial part. A similar situation was found in concentrations of these metals in all experimental units.

In plants that tendency of accumulation was observed in roots than in the aerial part. The concentration of metals in plants exhibited the following order: $\mathrm{Cu}>\mathrm{Zn}>\mathrm{Pb}>\mathrm{Cr}>\mathrm{Cd}$ in roots and the 
aerial part. No significant differences in germination percentage and average dry weight. Difference is observed respect to height in the three treatments reaching the higher average; the plants irrigated whit wastewater photochemical treated reaching a height $50.4 \mathrm{~cm}$ at 45 days after planting.
Phytotoxicity produced for the absorption of those heavy metals has not been determined, nevertheless, we need to take care of the concentration of these elements because they are bioaccumulative. Exists the feasibility for use photochemical treated wastewater after the advanced primary treatment for the irrigation of farming without phytotoxicity risk.

\section{REFERENCES}

1. Bates, B.C.; Kundzewics, Z.W.; Wu, S.; and Palutikof, J.P. Climate Change and Water. Technical paper. Intergovernmental Panel on Climate Change. Geneva, (2008).

2. Angelakis, A. N.; and B. Durham. Water recycling and reuse in EUREAU countries: Trends and challenges. Desalination, 218, 3-8, (2008).

3. Asano, T.; Burton, F.L.; Leverenz, H.L.; Tsuchihashi, R. and Tchobanoglous, G. Water reuse. Issues, technologies, and applications. Metcalf\& Eddy / AECOM. McGraw-Hill, New York. (2007).

4. Cirelli, G.L.; Consoli, S.; Licciardello, F.; Aiello, R.; Giuffrida F. and Leonardi, C. Treated municipal wastewater reuse in vegetable production. Agr. Water Manage. 104, 163-170 (2012).

5. Agrafioti, E.; and Diamadopoulos, E., A strategic plan for reuse of treated municipal wastewater for crop irrigation on the Island of Crete. Agri. Water Manage. 105, 57-64, (2012).

6. Liu, M.; Liu, X.; Hao, J. and Gao, L. Effect of simulated drought stress on plant growth, yield and fruit properties of tomato. Acta Horticulturae 856, 193-202 (2010)

7. FAO. 2008. AQUASTAT, FAO's Information System on Water and Agriculture. (Available in http://www.fao.org/nr/water/aquastat/ globalmaps/index.stm)

8. FAOWATER. 2008. Water at a Glance: The relationship between water, agriculture, food security and poverty. Rome, FAO. (Available in http://www.fao.org/nr/water/docs/ waterataglance.pdf).

9. Norma Official Mexicana NOM-002-ECOL-
1996, that establishes the maximum permissible limits of pollutants in wastewater discharges to urban systems or municipal sewer.

10. Zhao, W.; Ting, Y.R.; Chen, J.P.; Xing, C.H.; Xing, C.H. and Shi, S.Q. Advanced Primary Treatment of Waste Water using a bio-flocculation-adsorption sedimentation process, acta biotechnol. 20[1], 53-64 (2000).

11. Sandip, S.; Ruparelia, J.P. and Manish, L.P. A general review on Advanced Oxidation Processes for waste water treatment. International Conference on Current Trends in Technology. 1-7, (2011).

12. Mark, D. L. Tukey's Honestly Significant Difference (HSD) Encyclopedia of Research Design. Neil J. Salkind Ed. 1566-1571 (2010).

13. Statgraphics. 2010. Statgraphics Centurion XVI User Manual. Stat Point Technologies, Inc. E. S. A. 305. (2010).

14. Mojid, M.A.; Wyseure, G.C.L.; Biswas, S.K.; Hossain, A.B.M.Z. Farmers' perceptions and knowledge in using wastewater for irrigation at twelve peri-urban areas and two sugar mill areas in Bangladesh, Agri. Water Manage. 98[1], 79-86 (2010).

15. Pál M., Horváth E., Janda T., Páldi E. y Szalai G. Physiological changes and defense mechanisms induced by cadmium stress in maize. J. Plant Nutr. Soil Sci. 169, 239-246, (2006).

16. Leung H.M., Ye Z.H. y Wong M.H. Survival strategies of plants associated with arbuscular mycorrhizal fungi on toxic mine tailings. Chemosphere 66, 905-915, (2007). 